\title{
The golden jackal (Canis aureus) in Bosnia and Herzegovina: density of territorial groups, population trend and distribution range
}

\author{
Igor Trbojević1*, Tijana Trbojević2 ${ }^{2}$ Danijela Malešević ${ }^{1}$, Miha $\mathrm{Krofel}^{3}$
}

${ }^{1}$ University of Banja Luka, Faculty of Sciences, Mladena Stojanovića 2, 78000, Banja Luka, Bosnia and Herzegovina

${ }^{2}$ Independent University of Banja Luka, Faculty of Ecology, Veljka Mlađenovića 12e, 78000 Banja Luka, Bosnia and Herzegovina

${ }^{3}$ University of Ljubljana, Biotechnical Faculty, Department for forestry, Večna pot 83, SI-1000 Ljubljana, Slovenia; ORCID: orcid.org/0000-0002-2010-5219

*Corresponding author: ORCID: orcid.org/0000-0003-0781-7235; Cell phone: +38765646080 ; E-mail: igortrbojevic@yahoo.com

\begin{abstract}
In this article, we present the results of the first systematic surveys of golden jackal in Bosnia and Herzegovina $(\mathrm{B} \& \mathrm{H})$. The population status and distribution of the golden jackal (Canis aureus) in B\&H was largely unknown, and the few existing literature records mention their presence at only five localities in the country. We interviewed managers of all the hunting grounds in $\mathrm{B} \& \mathrm{H}$ and reviewed available jackal hunting records from 2000 to 2016. In total, we collected 212 records of legally harvested jackals. We observed an increasing trend of harvested jackals in $\mathrm{B} \& \mathrm{H}$ (on average $35 \%$ annual increase) during this same period. Using acoustic (play-back) method, we confirmed the presence of 80 territorial jackal groups along six transects covering $3081 \mathrm{~km}^{2}$. We estimated density to be a minimum of 0.33 groups $/ 10 \mathrm{~km}^{2}$ in northern $\mathrm{B} \& \mathrm{H}$ and 0.10 groups $/ 10 \mathrm{~km}^{2}$ in central $\mathrm{B} \& \mathrm{H}$. Jackal groups were located at significantly lower altitudes in respect to available area along the transects. We present a distribution map of confirmed jackal occurrences in $\mathrm{B} \& \mathrm{H}$, which indicates that the core area of jackal distribution in the country is currently located along the Sava River and its tributaries in the northern part of B\&H. Jackals are sporadically present in the rest of the country, where grey wolves (Canis lupus) probably limit their presence. In total, jackal presence has been detected in 19\% (109 out of 586) of 10x10 km grid cells covering the country. The primary factor driving expanding population of jackals in northern B\&H appears to be immigration of jackals from Croatia and Serbia.
\end{abstract}

Key words: golden jackal, Canis aureus, acoustic method, group density, expansion range, Bosnia and Herzegovina

\section{INTRODUCTION}

The golden jackal (Canis aureus Linnaeus, 1758) is considered a native species of the Balkan Peninsula (Milenković 1987; Kryštufek et al. 1997). The core population is located in the eastern part of the peninsula, mainly in Bulgaria (Kryštufek et al. 1997). During the last decades, the jackal population in South-eastern Europe expanded across the Balkan Peninsula and eventually 
into Central, Eastern and Northern Europe (Trouwborst et al. 2015; Krofel et al. 2017). While decreases in jackal population were observed in some localized areas (e.g., in Greece due to poisoning campaigns; Giannatos et al. 2005), in general, there is an increasing jackal population (Krofel et al. 2017). Currently researchers estimate that approximately 70,000 jackals live in Europe (Ćirović et al. 2016). Intensive persecution of grey wolves (Canis lupus) throughout Europe during the last 150 years caused local extinctions and wolf population decline. The decrease in wolf abundance is likely a key driver that triggered jackal expansion across the continent (Krofel et al. 2017). Golden jackals are highly adapted to living in human-modified habitats where they take advantage of human presence and accessible food sources (Bošković et al. 2013; Ćirović et al. 2014; 2016; Penezić and Ćirović 2015), which, together with changes in land use, hunting management, and climate, likely eased the expansion process (Krofel et al. 2017).

While several studies were initiated across the jackal range in Europe to determine species' distribution and local densities (e.g., Šálek et al. 2014; Kowalczyk et al. 2015, Trouwborst et al. 2015; Ivanov et al. 2016; Krofel et al. 2017), almost no information was available for Bosnia and Herzegovina $(\mathrm{B} \& \mathrm{H})$. The existing data suggest that the presence of jackals is sporadic and limited to five locations: two near vicinity of Stolac, one in Mliništa (vicinity of Glamoč) (Milenković 1987), one in Ljekova (vicinity of Trebinje) (Mitchell-Jones et al. 1999) and one in Hutovo blato (vicinity of Čapljina) (Kryštufek et al. 1997) (Fig 2). All of these areas are found in the southern part of the country, in Herzegovina. However, recent hunting records suggest that the core of population could be located in northern part of the country (Trbojević and Malešević 2014), but there were no attempts to systematically collect data, estimate the distribution, population trend, and densities of golden jackals in the country, where they have status of a hunted species (Trouwborst et al. 2015).

Our work is an attempt to provide the first reliable estimate of golden jackal distribution, population trend, local densities of territorial jackal groups, and preference of elevation in $\mathrm{B} \& \mathrm{H}$. This information is vital for future management of this species in the country and to improve our understanding of jackal expansion across Europe.

\section{MATERIAL AND METHODS}

\section{Study area}

We gathered hunting records of jackals from 2000 to 2016 from all hunting grounds across the country $(n=207)$ through interviews with hunting ground managers and by reviewing hunting magazines and daily newspapers. This enabled us to approximate jackal distribution and population trend at the national level. The country-wide survey allowed us to select areas for a detailed study of jackal group densities with the use of acoustic method. Acoustic survey was conducted along six transects in two parts of the country (northern and central part). Division into northern and central part was introduced to separate between the two regions with different abundance of hunting records (higher in the north), presence of grey wolves (more widespread in the central part), and topography (mountainous in the central part).

The first transect was located in the north of Bosnia and Herzegovina $(\mathrm{B} \& \mathrm{H})$, from the town of Novi Grad $\left(45^{\circ} 02^{\prime} 52^{\prime \prime} \mathrm{N}, 16^{\circ} 22^{\prime} 45^{\prime \prime} \mathrm{E}\right)$, along the valley of the Sava River to Bijeljina $\left(44^{\circ} 45^{\prime} 25^{\prime \prime} \mathrm{N}, 19^{\circ} 12^{\prime} 54^{\prime \prime} \mathrm{E}\right)$, to the Drina River, and to the mountains of Central B\&H. In this region, we chose three transects: "Sava", "Posavina", and "Krajina" (Fig 1). Most of the area is located below $200 \mathrm{~m}$, with individual hills reaching up to $589 \mathrm{~m}$. In the second study area, we sampled three transects in the mountainous central B\&H, from the town of Banja Luka 


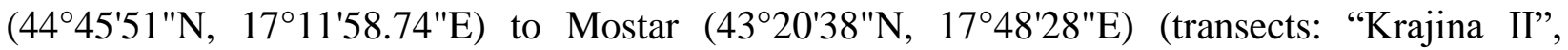
"Central Bosnia" and "Jablanica"; Fig 1). This area is located between 200-1416 m, mostly 540$1010 \mathrm{~m})$.

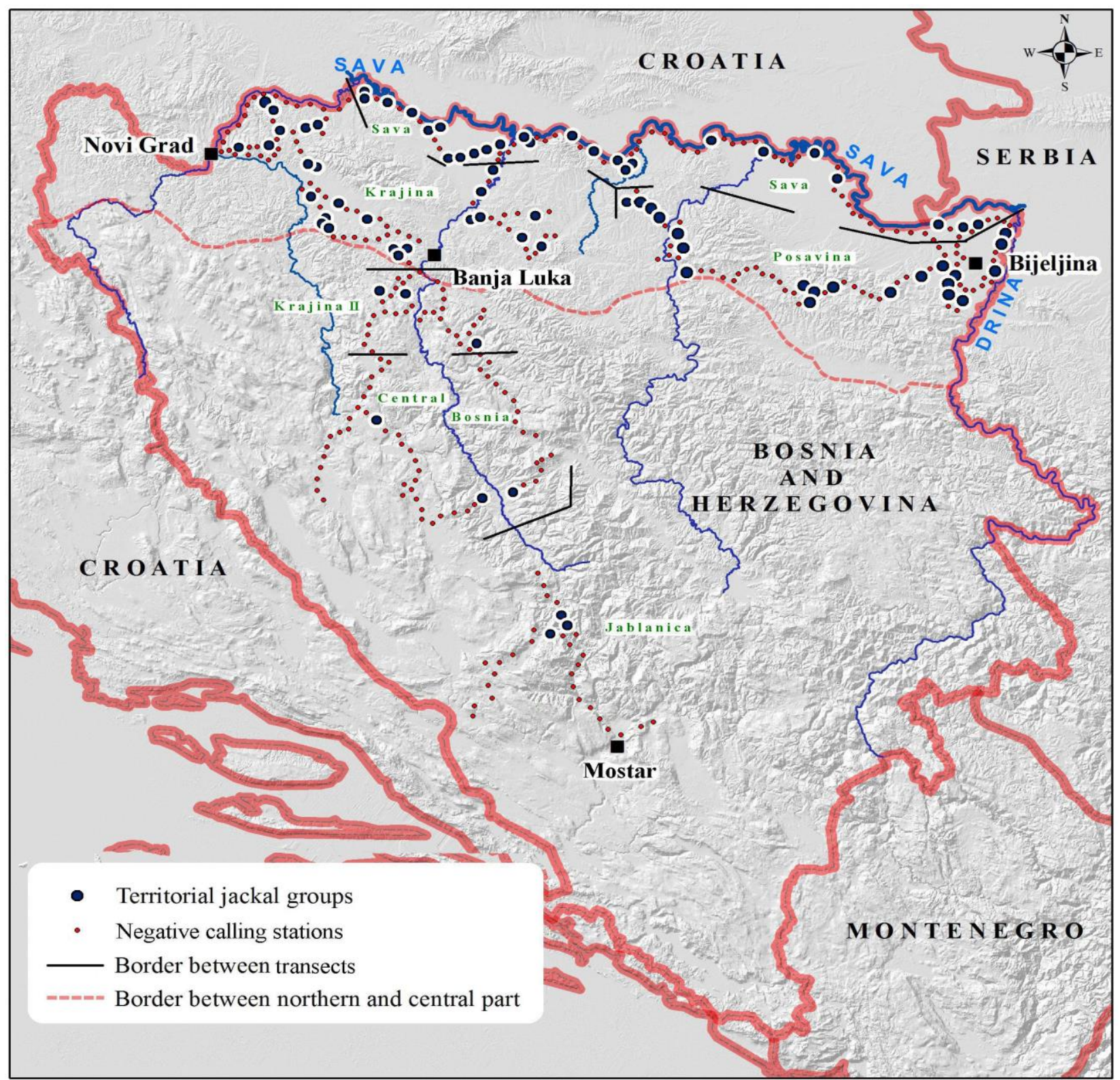

Fig 1 Map of Bosnia and Herzegovina with shown locations of recorded territorial jackal groups and calling stations without recorded responses (negative calling stations).

\section{Hunting records}

We collected data about the jackals harvested (i.e. legally shot) annually across the B\&H between 2000 and 2016 through personal interviews with hunting ground managers (i.e., representatives of hunting and forestry organizations, national parks and nature parks), available hunting statistics, and records published in national hunting magazines and local daily press. These data 
were used to provide information about the trend of the jackal population in $\mathrm{B} \& \mathrm{H}$ on the national level.

Personal interviews with managers of all hunting grounds in the country $(n=207)$ were conducted four times during the study period (2013/2014, 2014/2015, 2015/2016 and 2016/2017) by two of the authors (I.T. and T.T.). Each time, interviews were conducted with managers of all hunting grounds in $\mathrm{B} \& \mathrm{H}$ in order to ensure equal coverage across the entire country. During the interviews, we collected records of any jackals harvested, and we reviewed unpublished hunting reports that gamekeepers keep for internal use. For each harvested jackal or animal that could potentially be jackal (e.g., "dwarf wolf", "dog-wolf" or "wolf-fox hybrid"), we asked for a photograph or trophy of the harvested animal in order to verify the identification of the species. In all of these cases, we could confirm that the harvested animal was indeed a jackal. At the same time, we checked the managers' knowledge about jackals by asking them questions about jackals' appearance and biology. With managers from the hunting grounds that did not report any harvested jackals, we checked their ability to recognize the species by showing them photographs of jackals, wolves, and foxes and asking them to identify the species. This was necessary to determine that the hunters did not accidentally kill jackals without being aware of it. Overall, knowledge about jackals was relatively poor, but all hunting ground managers were able to recognize jackals from a photograph and distinguished it from wolf and fox.

We systematically reviewed all hunting magazines published in B\&H from 2000 to 2014 to obtain information about (usually) the first shooting or sighting of jackals in a given area. We also included opportunistically collected records of harvested jackals from daily newspapers. In this way, we tried to complete the records by adding incidents that were missed during the interviews and review of hunting records, especially in the first years of our study period. We confirmed that most $(97 \%)$ of the cases published in the hunting magazines and daily newspapers were also included in the database obtained during the interviews ( 5 out of 147 records published in the magazines and newspaper were missed during the interviews).

\section{Acoustic (play-back) method}

In most of the regions with detected jackal presence through hunting records we surveyed density of jackal territorial groups using acoustic (play-back) method (Giannatos et al. 2005), from October 2016 to the end of February 2017. The distance between neighboring calling stations along transects was 3-4 km (Giannatos et al. 2005; Krofel 2008; Banea et al. 2012). Calling stations were selected according to topographical characteristics in order to optimize sound transmission (e.g., using higher areas and avoiding roads and other sources of noise; Banea et al. 2012; Š́lek et al. 2014). We did not conduct fieldwork during windy or rainy nights, and we always began the survey at least one hour after sunset and finished at least one hour before sunrise. From each calling station, a recorded group yip-howl by two to four jackals was broadcasted (records were made in Hungary and Slovenia). We used a Megaphone 50-Watt ETRION MR in connection with a mobile phone. Each broadcasted howl lasted for 30 seconds and was followed by a 5 minutes pause. This set of broadcast and pause was repeated six times, unless a response from jackals was elicited. When jackals responded to the broadcast, we determined the direction of howling jackals using a compass and estimated the distance based on the volume of the howling and, when possible, visual sighting of the responding jackals was recorded (Banea et al. 2012). In order to avoid double counting, we marked each response direction on topographical maps 1:25.000. Geographical coordinates and altitude of calling stations with and without response were recorded with a handheld GPS. After each response, we also scanned the area with a spotlight at calling stations located in open habitats. 
For the calculation of jackal territory densities, we followed Giannatos et al. (2005), Szabó et al. (2007) and Š́lek et al. (2014), who reported that the maximum human hearing distance on windless nights with no background noise is $2 \mathrm{~km}$ and estimated the effective area for an audible response from jackals to $12.57 \mathrm{~km}^{2}$. We used the same approach to ensure comparability of our results with previous studies on jackals in Europe. If sound of transmission was hindered in one of the directions due to topographical features, we subtracted the corresponding share of the effective area, i.e., when we estimated that topographic obstacle hindered sound transmission to one of the directions, we subtracted one quarters of the area and used $9.43 \mathrm{~km}^{2}$ value for the calculation of effective area covered (similar to Krofel 2008 and Banea et al. 2012). Sound transmission was not hindered in more than one direction at any of the calling stations. It was assumed that only territorial groups of jackals were responding to the broadcasted howls and that each response direction coincided with a different territorial group (Giannatos et al. 2005; Krofel 2008). We used Wilcoxon rank sum test in program $\mathrm{R}$ version 3.2.0 to compare altitudes of calling stations with jackal response to the altitudes of all calling stations. All maps were produced using the program QGIS.

\section{Distribution map}

All data collected from the hunting records, acoustic surveys, and historical records (Milenković 1987, Mitchell-Jones et al. 1999, Kryštufek et al. 1997) were merged to present the minimum distribution of the golden jackal in $\mathrm{B} \& \mathrm{H}$. We mapped collected occurrences of golden jackal from across the country and calculated the proportion of occupied cells of the $10 \times 10 \mathrm{~km}$ European grid (using ETRS89 projection) in B\&H (586 grid cells). Each observation is shown as one occurrence, even if several individuals were observed. To indicate relative abundance, we also show the number of records per each cell. However, for this purpose, we only used hunting records, which were systematically collected over the entire country, because acoustic surveys were conducted only in some parts of the country and effort was unknown for collection of historical records.

\section{RESULTS}

\section{Distribution of golden jackal in Bosnia and Herzegovina}

In total, we collected 297 records (80 jackal groups detected during acoustic survey, 212 hunting records and five historical records) of golden jackal throughout Bosnia and Herzegovina (B\&H). So far, presence of jackals has been detected in 19\% (109 out of 586) of 10x10 km grid cells in the country (Fig 2).

In total, 212 records of harvested jackals were collected. Among them, 207 records were obtained through interviews with hunting ground managers and 147 from hunting magazines and newspaper publications (data on 142 harvested animals were obtained from both sources). Jackals were reported harvested in $36.7 \%$ (76 out of 207) of hunting grounds across the country from 2000 to 2016 (Fig 2). In the remaining 131 hunting grounds, there were no recorded killings of jackals, nor did managers' report any detected signs of jackal presence in these hunting grounds. The reported number of jackals harvested per year ranged from a minimum of 1 in 2000 to the maximum of 39 in 2016. Trend was increasing in time with an average increase of $35 \%$ annually (Fig 3). The mean altitude $( \pm \mathrm{SD})$ of recorded harvested jackals was $261 \pm 238 \mathrm{~m}$ a.s.1. (range: 79 $1203 \mathrm{~m})$. 


\section{Density and altitudinal distribution of jackal territorial groups}

An acoustic survey was conducted during 23 nights, from October 2016 to February 2017. The total area covered by the six transects was $3081 \mathrm{~km}^{2}$. Jackal howling was broadcasted from 341 calling stations distributed across 122 grid cells. These included 38 grid cells with records of harvested jackals (56\% of 68 grid cells with records of harvested jackals).

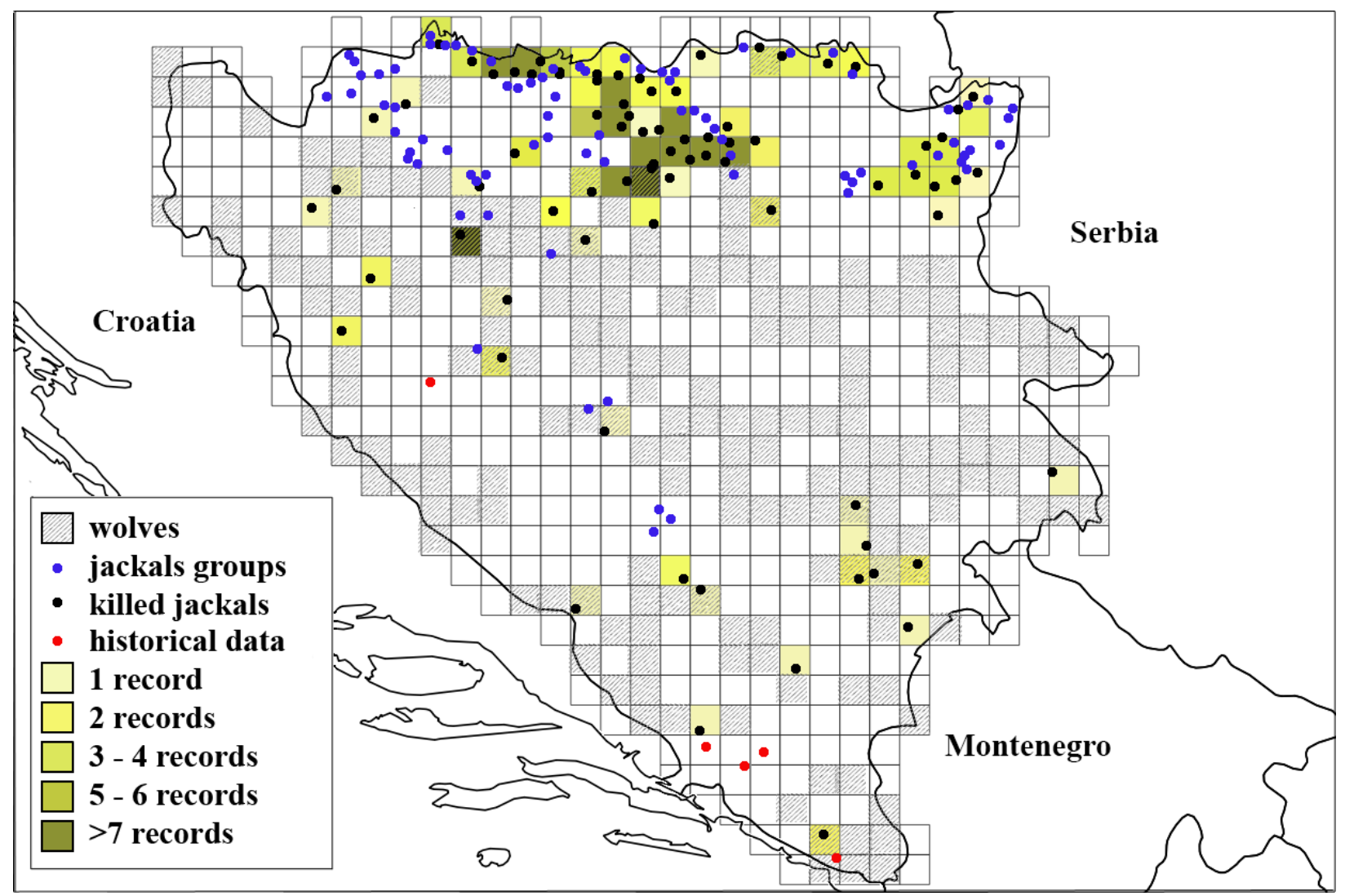

Fig 2 Distribution of golden jackals and grey wolves in Bosnia and Herzegovina. Red dots represent historical records of harvested or observed jackals in period 1970-1987 (data source: Kryštufek et al. 1997; Milenković 1987; Mitchell-Jones et al. 1999). Intensity of yellow-green coloring of the $10 \times 10 \mathrm{~km}$ grid cells indicate the number of jackals harvested in 2000-2016, which were sampled over entire country and black dots represent their exact locations. Blue dots represent locations of jackal groups found during the acoustic survey in 2016-2017 (transects with calling stations are shown on Fig. 1). Grey hatching represents the distribution of wolves (after Trbojević 2016).

Responses of territorial jackals were noted at $71(20.8 \%)$ calling stations (Table 1). In total, 80 different territorial jackal groups were recorded, which amounts to the overall minimum density estimate of 0.26 territorial jackal groups $/ 10 \mathrm{~km}^{2}$. The mean $( \pm \mathrm{SD})$ altitude of the calling stations with detected territorial jackal groups was $226 \pm 166 \mathrm{~m}(n=71)$, which was significantly lower compared to the altitudes of all calling stations $(372 \pm 335 \mathrm{~m}, n=271$; Wilcoxon rank sum test: $W$ $=2556, p<0.001)$. In total, we observed four jackal groups with average size $( \pm \mathrm{SD})$ of $4.3 \pm 2.2$ individuals.

Total length of transects in the northern B\&H was $866 \mathrm{~km}$ (transects "Sava" $272 \mathrm{~km}$; "Posavina" $258 \mathrm{~km}$ and "Krajina" $344 \mathrm{~km}$; Fig 1) and covered $2168 \mathrm{~km}^{2}$. Jackal howling was broadcasted 
from 219 calling stations, and responses were noted at $62(28.3 \%)$ calling stations (transect "Sava" - 22 calling stations; transect "Posavina" - 18 calling stations and transect "Krajina" -22 calling stations; Table 1).

Table 1 Summary of the results of the acoustic surveys of golden jackals in Bosnia and Herzegovina from October 2016 to February 2017.

\begin{tabular}{|c|c|c|c|c|c|}
\hline Transects & $\begin{array}{c}\text { Area } \\
\text { covered } \\
\left(\mathrm{km}^{2}\right)\end{array}$ & $\begin{array}{l}\text { Number } \\
\text { of calling } \\
\text { stations }\end{array}$ & $\begin{array}{l}\text { Number of } \\
\text { stations } \\
\text { with } \\
\text { responses }\end{array}$ & $\begin{array}{l}\text { Number of } \\
\text { territorial } \\
\text { groups }\end{array}$ & $\begin{array}{c}\text { Minimum } \\
\text { density of jackal } \\
\text { groups } / 10 \mathrm{~km}^{2}\end{array}$ \\
\hline \multicolumn{6}{|c|}{ Northern Study area } \\
\hline Sava & 720 & 68 & 22 & 25 & 0.38 \\
\hline Posavina & 703 & 65 & 18 & 21 & 0.30 \\
\hline Krajina & 745 & 86 & 22 & 25 & 0.34 \\
\hline Total North & 2168 & 219 & 62 & 71 & 0.33 \\
\hline \multicolumn{6}{|l|}{ Central Study area } \\
\hline Krajina II & 302 & 33 & 3 & 3 & 0.10 \\
\hline Central Bosnia & 381 & 57 & 3 & 3 & 0.08 \\
\hline Jablanica & 230 & 32 & 3 & 3 & 0.13 \\
\hline Total Central & 913 & 122 & 9 & 9 & 0.10 \\
\hline TOTAL & 3081 & 341 & 71 & 80 & 0.26 \\
\hline
\end{tabular}

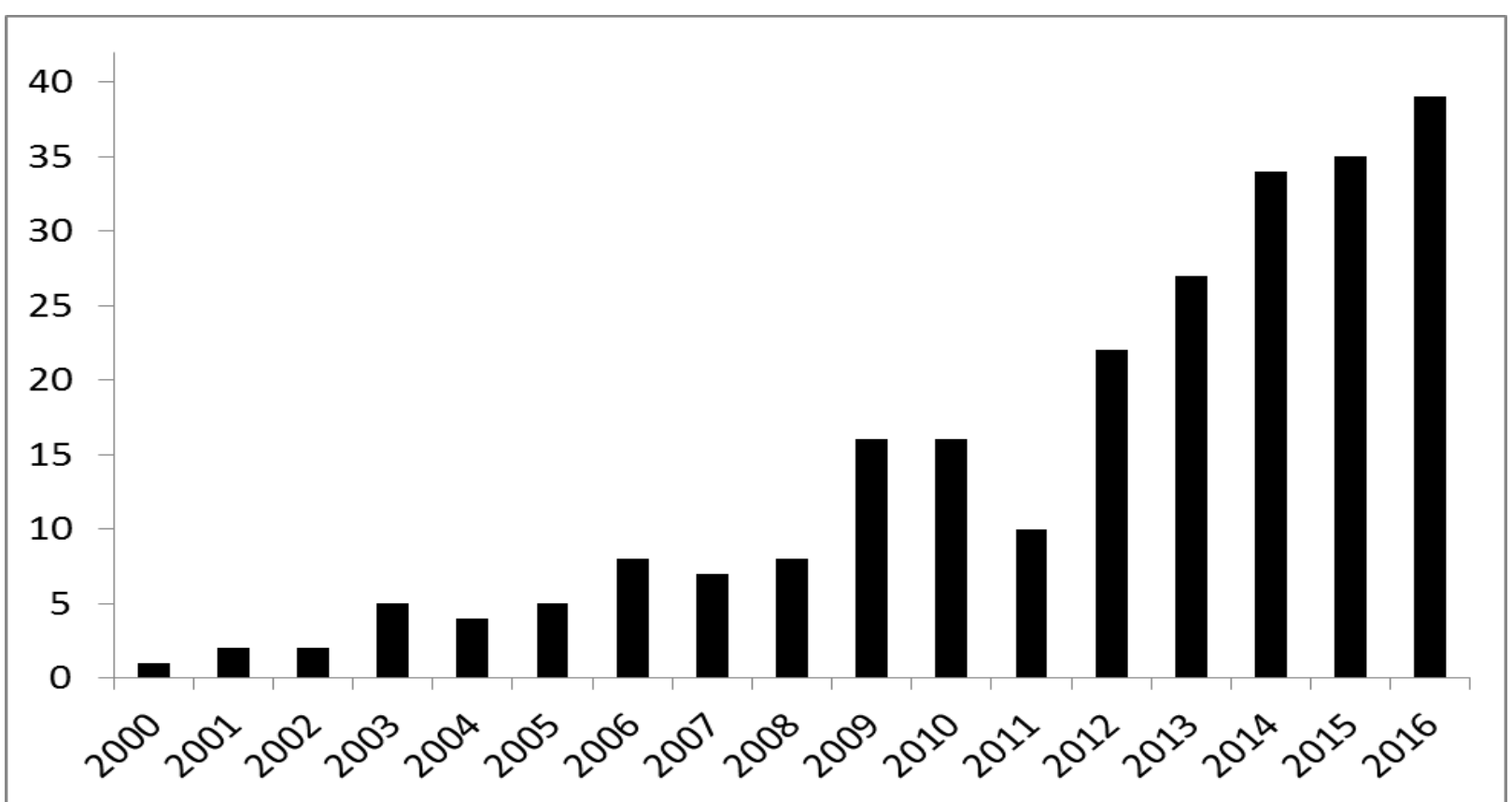

Fig 3 Hunting records of jackals harvested in Bosnia and Herzegovina in the period 2000-2016 $(n=212)$. 
We recorded 71 territorial jackal groups, which amounts to the minimum density estimate 0.33 groups $/ 10 \mathrm{~km}^{2}$ (range among transects: $0.30-0.38$ groups $/ 10 \mathrm{~km}^{2}$; Table 1 ). The mean altitude $( \pm \mathrm{SD})$ of recorded territorial groups was $178 \pm 97 \mathrm{~m}$ a.s.l. (range: $76-433 \mathrm{~m}$ ). Fifty territorial groups were found at altitudes below $200 \mathrm{~m}$ while the other 21 were found between $200-433 \mathrm{~m}$ (Fig 4). At three locations, we were able to observe jackal groups that approached us up to 9-10 $\mathrm{m}$. One group consisted of five individuals (near the town of Bijeljina), the second of three individuals (near the town of Gradiška), and the third of two individuals (on the bank of the Drina River, the border with Serbia).

The three transects, in central B\&H were $494 \mathrm{~km}$ in length ("Krajina II" $135 \mathrm{~km}$; "Central Bosnia" $222 \mathrm{~km}$ and "Jablanica" $137 \mathrm{~km}$; Fig. 1) and covered $913 \mathrm{~km}^{2}$. Jackal howling was broadcasted from 122 calling stations and responses were noted at $9(7.4 \%)$ calling stations ("Krajina II" - 3, "Central Bosnia" - 3, "Jablanica" - 3). We recorded 9 territorial jackal groups, which amounts to the minimum density estimate 0.10 groups $/ 10 \mathrm{~km}^{2}$ (range: $0.08-0.13$ groups/10 $\mathrm{km}^{2}$; Table 1). The mean altitude $( \pm \mathrm{SD})$ of recorded territorial groups was $557 \pm 168 \mathrm{~m}$ a.s.l. (range: 292-760 m; Fig 4). At one location (mountain Manjača), we were able to observe a group of seven jackals, which approached us at approximately $10 \mathrm{~m}$, and one individual near the town of Jablanica.

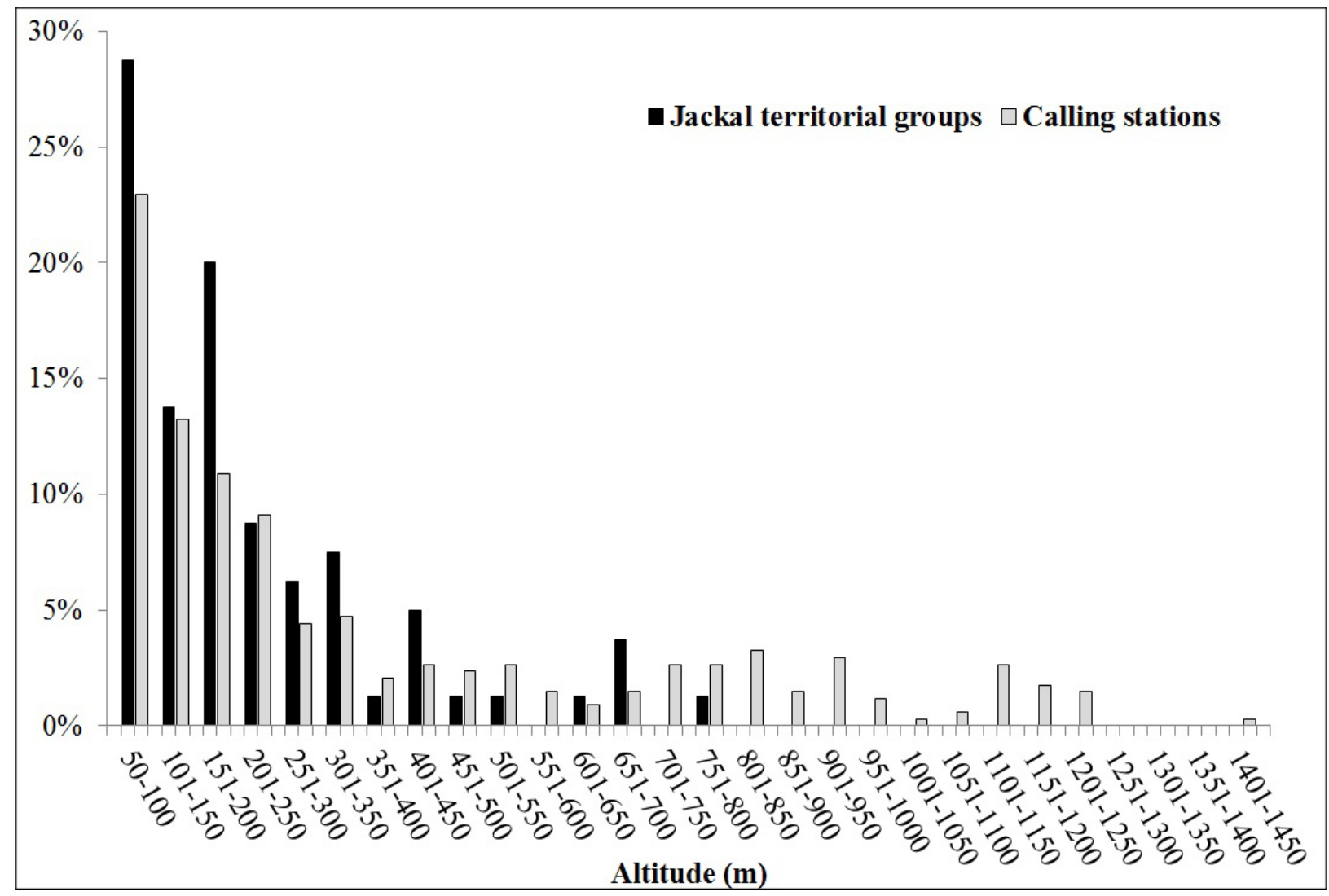

Fig 4 Distribution of territorial jackal groups detected during acoustic survey (black; $n=80$ ) and calling stations (grey; $n=341$ ) in respect to altitude intervals in Bosnia and Herzegovina. 


\section{DISCUSSION}

This study provides important new information that improves our understanding of golden jackal status in Bosnia and Herzegovina (B\&H). Specifically, our work offers first reliable estimates of minimum jackal group densities, approximated population trend, and new data on the range distribution of jackals in $\mathrm{B} \& \mathrm{H}$.

Because we surveyed jackals with the acoustic method only in the northern and central parts of the country and during a short period, it was not possible to use this data to estimate jackal distribution or evaluate the population trends across the entire B\&H. Therefore, we used hunting records, which we collected over the entire country for a 17-year period, to better understand current distribution and general trend in the population dynamic of jackals in B\&H. Despite their limitations, hunting records are regularly used in similar studies to derive indices of predator abundance and distribution (e.g. Elmhagen and Rushton 2007; Newsome et al. 2017), and this is currently the only type of long-term data available on the national level in $\mathrm{B} \& \mathrm{H}$. Because the trend in hunting records is relatively clear and in accordance with similar data in other parts in the Balkans (Ćirović et al. 2008, 2016; Š́lek et al. 2014; Trouwborst et al. 2015; Ivanov et al. 2016; Krofel et al. 2017), we believe that it reflects a genuine increasing trend in the population. However, we do acknowledge that results should be treated with caution, as it is not possible to estimate the exact level of population growth from the increase shown in hunting records. Also the distribution range could be underestimated because some of the harvested jackals may not have been reported or were missed due to misidentification by the hunters. Additionally, jackal hunting may have not taken place in all areas where the species is present, especially where it occurs sporadically or in low densities.

Although hunting ground managers could recognize the jackal from the photos, even where the species is not regularly present, we have often noticed during the interviews that their knowledge about this species is relatively poor (e.g., they were frequently called "mixed-breed of dog and wolf" or "little wolf). This is not surprising since until recently, the jackals were rarely present in $\mathrm{B} \& \mathrm{H}$. During the last ten years, interest in this species has increased among hunters and the public, which is probably connected with the increasing trend in population, as well as with livestock depredations (Bešlić 2014; Trbojević and Trbojević 2017).

Although we observed high local variation in densities of jackal territorial groups, the average density in both study areas was relatively low compared to results obtained with the same method in most of the other countries in the Balkan Peninsula and Central Europe: 0.6 groups $/ 10 \mathrm{~km}^{2}$ in Bulgaria, 1.1 groups $/ 10 \mathrm{~km}^{2}$ in Serbia, $0.7-2.4$ groups $/ 10 \mathrm{~km}^{2}$ in Croatia, $0.2-2.6$ groups $/ 10 \mathrm{~km}^{2}$ in Romania, 1.4-3.0 groups $/ 10 \mathrm{~km}^{2}$ in Hungary, $0.05-0.3$ groups $/ 10 \mathrm{~km}^{2}$ in Slovenia and 0.8-5.0 groups $/ 10 \mathrm{~km}^{2}$ in Greece (Giannatos et al. 2005; Szabó et al. 2007; Krofel 2008; Banea et al. 2012; Śálek et al. 2014; Mladenović 2016; Krofel 2018). In some areas in Greece and Hungary, local concentrations as high as 30 animals $/ 10 \mathrm{~km}^{2}$ and 13.3 groups $/ 10 \mathrm{~km}^{2}$ were reported (Giannatos 2004; Szabó et al. 2008). This suggests that there is potential for further growth in the population size in $\mathrm{B} \& \mathrm{H}$ in the future.

We noted that the density of territorial groups in mountainous parts of $\mathrm{B} \& \mathrm{H}$ (central part) was considerably lower $\left(0.1\right.$ groups $\left./ 10 \mathrm{~km}^{2}\right)$ than the lowlands in the north $\left(0.33\right.$ groups $\left./ 10 \mathrm{~km}^{2}\right)$. This corresponds to the data of hunting records, as well as the preference for lower altitudes that we observed within our transects, and previously reported preferences from other areas in Europe (e.g., Giannatos et al. 2005). Nevertheless, acoustic data showed that territorial groups live in $\mathrm{B} \& \mathrm{H}$ up to at least $760 \mathrm{~m}$ a.s.l., and the hunting records reported jackals occurring as high as $1203 \mathrm{~m}$ a.s.l. In other countries, jackals are rarely reported from altitudes higher than $1050 \mathrm{~m}$ 
(Giannatos et al. 2005). In addition, lower jackal densities in the mountainous regions could be partly explained by the presence of grey wolf, as this apex predator is, in general, more abundant in the regions where we observed lower jackal densities (Fig 2). This corresponds to previous studies on effects of wolf presence on jackal distribution in Europe (Krofel et al. 2017; Newsome et al. 2017).

While reports from the second half of the 20th century (Kryštufek et al. 1997; Milenković 1987; Mitchell-Jones et al. 1999) suggested that the golden jackal is limited to the southern part of the country, its current distribution, as shown in this study, suggests that a large part of the population is located in the northern part of in $\mathrm{B} \& \mathrm{H}$. Whether this is a consequence of biased sampling in the past or recent expansion to northern B\&H is difficult to assess. Given the documented increase in population size in the last years, we assume that recent expansion to this area is a possible explanation.

The origin of jackals in $\mathrm{B} \& \mathrm{H}$ is not clear due to a lack of genetic analysis. Like most of the jackals in Europe, they likely originate from the Caucasian region and from historic populations that have been established in Greece and the Adriatic coast since at least the Neolithic era (Rutkowski et al. 2015; Krofel et al. 2017). Given the higher number of territorial groups we recorded along the borders with Croatia and Serbia and increasing trends recently reported from these countries, especially along the Sava River (Ćirović et al. 2008; Bošković 2009; Faculty of Agriculture 2015; Śálek et al. 2014), which corresponds to recent population trend in our study area, we suggest that the observed increase of jackal records in $\mathrm{B} \& \mathrm{H}$ is primarily connected to immigration from Croatia and partly (for north-eastern part of B\&H) from Serbia.

\section{CONCLUSIONS}

This study provides the first systematically collected data about jackal population distribution, trend, and local densities of territorial groups in Bosnia and Herzegovina $(\mathrm{B} \& \mathrm{H})$, which is a considerable advancement, from the limited information available prior to this work. The jackal population appears to have increased substantially in the previous decades, especially in the northern lowlands of $\mathrm{B} \& \mathrm{H}$. Our results stress the need to establish national monitoring of jackals both in $\mathrm{B} \& \mathrm{H}$ and neighboring countries, including a reliable hunting database and development of a jackal management plan. Given relatively poor understanding of jackal ecology in $\mathrm{B} \& \mathrm{H}$, it would also be important to initiate research, particularly concerning the potential impact of jackal on game and domestic animals. Dissemination reliable information among the hunters and other key stakeholders in the country is also necessary to improve the public knowledge about this species.

\section{Acknowledgements}

We want to thank to Marko Ivanišević for helping with the preparation of maps, and Jennifer C. Ellis and Nataša Baštinac for improving the English. We are also grateful to Duško Ćirović and Krzystof Schmidt for constructive comments, and two anonymous reviewers for reviewing the early draft and providing several useful suggestions that considerably improved the manuscript. MK was funded by the Slovenian Research Agency (grant no. P4-0059)

\section{References}

Banea OC, Krofel M, Červinka J, Gargarea P, Szabo L (2012) New Records, first Estimates of Densities and Questions of Applied Ecology for Jackal in Danube Delta Biosphere Reserve and Hunting Terrains from Romania. Acta Zool Bulg 64:353-366. 
Bešlić M (2014) Invasion by jackals. In: Hoop! Hunting magazine, Voice of the Hunting Association of Herzeg Bosnia and the Kinological Association of Herzeg Bosnia. Issue 92, January - February, XVII year. SUTON d.o.o. Široki Brijeg, Bosnia and Herzegovina. 13 pp. (In Croatian)

Bošković I (2009) Jackal - Croatian autochthonous game species. Hunting Journal 6:44-49. (In Croatian)

Bošković I, Florijančić T, Šperanda M, Šprem N, Ozimec S, Degmečić D (2013) Population status of jackals (Canis aureus L.) in eastern Croatia. Proceedings of the 48th Croatian and 8th International Symposium of Agronomy, 17-22 February 2013 Dubrovnik, Croatia. (In Croatian)

Ćirović D, Milenković M, Paunović M, Penezić A (2008) Actual distribution and factors of spreading of jackals (Canis aureus L. 1758) in Serbia. In: International conference on large carnivores and seekers by blood. Hunting Association of Serbia. Žagubica: 93-102 pp. (In Serbian with English summary)

Ćirović D, Penezić A, Milenković M, Paunović M (2014) Winter diet composition of the golden jackal (Canis aureus) in Serbia. Mamm Biol 79:132-137.

Ćirović D, Penezić A, Krofel M (2016) Jackals as cleaners: Ecosystem services provided by a mesocarnivore in human-dominated landscapes. Biol Conserv 199:51-55.

Elmhagen B, Rushton SP (2007) Trophic control of mesopredators in terrestrial ecosystems: topdown or bottom-up? Ecol Lett 10:197-206

Faculty of Agriculture (2015) Technical basis for determining the basic determinant of residence, status and management guidelines with jackal (Canis aureus L.) in Republic of Croatia. Ministry of Agriculture and Faculty of Agriculture in Osijek. Osijek: 77 pp. (In Croatian)

Giannatos G (2004) Conservation Action Plan for the golden jackal Canis aureus L. in Greece. WWF Greece.

Giannatos G, Marinos Y, Maragou P, Catsadorakis G (2005). The status of the golden jackal (Canis aureus L.) in Greece. Belg J Zool 135:145-149.

Ivanov G, Karamanlidis AA, Stojanov A, Melovski D, Avukatov V (2016). The re-establishment of the golden jackal (Canis aureus) in FYR Macedonia: Implications for conservation. Mamm Biol 81:326-330.

Kowalczyk R, Kołodziej-Sobocińska M, Ruczyńska I, Wójcik JM (2015) Range expansion of the golden jackal (Canis aureus) into Poland: first records. Mamm Res 60:411-414

Krofel M (2008) Survey of golden jackals (Canis aureus L.) in Northern Dalmatia, Croatia: preliminary results. Natura Croatica 17:259-264.

Krofel M, Giannatos G, Ćirović D, Stoyanov S, Newsome TM (2017) Golden jackal expansion in Europe: a case of mesopredator release triggered by continent-wide wolf persecution? Hystrix, 28(1): OnlineFirst. doi: 10.4404/hystrix-28.1-11819

Krofel M (2018) Wolves and jackals in Primorska. In: Pavčič J (ed) Slovenska Istra. Slovenska matica, Ljubljana, in press (In Slovenian with English summary)

Krystufek B, Murariu D, Kurtonur C (1997) Present distribution of the golden jackal Canis aureus in the Balkans and adjacent regions. Mamm Rev 27:109-114.

Milenković M (1987) The distribution of the jackal, Canis aureus Linnaeus, 1758. (Mammalia, Canidae) in Yugoslavia (in Serbian). Fauna of SR Serbia, Serbian Academy of Sciences and Arts. 4:233-248. 
Milenković M, Paunović M (2003) Phenomenon of golden jackal (Canis aureus L., 1758) expansion in Serbia. In: Meeting report of the Carpathian Workshop on Large Carnivore Conservation. Romania, Brasov: $35 \mathrm{pp}$.

Mitchell-Jones A.J, Amori G, Bogdanowicz W, Krystufek B, Reijenders P.J.H, Spitzenberger F, Stubbe M, Thissen J.B.M, Vobralik V, Zima J (1999) The Atlas of European Mammals. Academic Press, London.

Mladenović J (2016) Population densities and habitat use of the golden jackal in Croatia and Slovenia. Master thesis. University of Ljubljana. (In Slovenian with English summary)

Newsome MT, Aaron C. Greenville CA, Ćirović D, Christopher R. Dickman RC, Johnson NC, Krofel M, Letnic M, Ripple JW, Ritchie GE, Stoyanov S, Wirsing JA (2017) Top predators constrain mesopredator distributions. Nat Commun 8:15469 doi: $0.1038 / \mathrm{ncomms} 15469$

Penezić, A., Ćirović, D (2015) Seasonal variation in the diet of the golden jackal (Canis aureus) in Serbia. Mammal Res 60:309-317.

Rutkowski R, Krofel M, Giannatos G, Ćirović D, Männil P, Volokh AM, Lanszki J, Heltai M, Szabó L, Banea O.C, Yavruyan E, Hayrapetyan V, Kopaliani N, Miliou A, Tryfonopoulos GA, Lymberakis P, Penezić A, Pakeltytė G, Suchecka E, Bogdanowicz W (2015) A European Concern? Genetic Structure and Expansion of Golden Jackals (Canis aureus) in Europe and the Caucasus. Plos One 10: e0141236

Šálek M, Červinka J, Banea OC, Krofel M, Ćirović D, Selanec I, Penezić A, Grill S, Riegert J (2014) Population densities and habitat use of the golden jackal (Canis aureus) in farmlands across the Balkan Peninsula. Eur J Wildl Res 60:193-200. doi: 10.1007/s10344-013-0765-0.

Szabó L, Heltai M, Lanszki J, Szücs E (2007) An indigenous predator, the golden jackal (Canis aureus L. 1758) spreading like an invasive species in Hungary. Bulletin USAMV-CN, 63-64.

Szabó L, Heltai M, Lanszki J (2008) Factors that influence the Golden jackal's (Canis aureus L. 1758) spreading in Hungary. 92nd Annual Meeting of the German Society of Mammalogy. Vienna. Abstracts of Oral Communications and Poster Presentations. Mammalian Biology, Special Issue 73: 41.

Trbojević I (2016) Distribution of grey wolf (Canis lupus L., 1758) in Bosnia and Herzegovina. Bulletin of Faculty of Forestry, University of Banja Luka 25:41-49. (In Serbian with English summary).

Trbojević I, Malešević D (2014) Distribution and status of golden jackal Canis aureus in Bosnia and Herzegovina. First International Jackal Symposium, 13-16 October 2014 Veliko Gradište, Serbia.

Trbojević T, Trbojević I (2017) Invasive expansion of the golden jackals in Bosnia and Herzegovina. International Scientific Conference, Forest Science for Sustainable Development of Forests, 7-9 December 2017 Banja Luka, Bosnia and Herzegovina.

Trouwborst A, Krofel M, Linnell JC (2015) Legal implications of range expansions in a terrestrial carnivore: the case of the golden jackal (Canis aureus) in Europe. Biodivers Conserv 24:2593-2610.

Cite this article as:

Trbojević, I., Trbojević, T., Malešević, D., Krofel, M. (2018). The golden jackal (Canis aureus) in Bosnia and Herzegovina: density of territorial groups, population trend and distribution range. Mamm Res https://doi.org/10.1007/s13364-018-0365-1 